\title{
A Good Quality Service Provision in the Network Service in Ghana: A Case Study of MTN Ghana
}

\author{
Alhassan Bunyaminu ${ }^{1} \&$ Fidelis Quansah ${ }^{2}$ \\ ${ }^{1}$ Lecturer, Banking and Finance Department, University of Professional Studies, Accra, Ghana \\ ${ }^{2}$ Lecturer, Marketing Department, University of Professional Studies, Accra, Ghana \\ Correspondence: Alhassan Bunyaminu, Banking and Finance Department, University of Professional Studies, \\ P.O. Box LG 149, Legon, Accra, Ghana. Tel: 233-24-6429-0969. E-mail: albun7@gmail.com
}

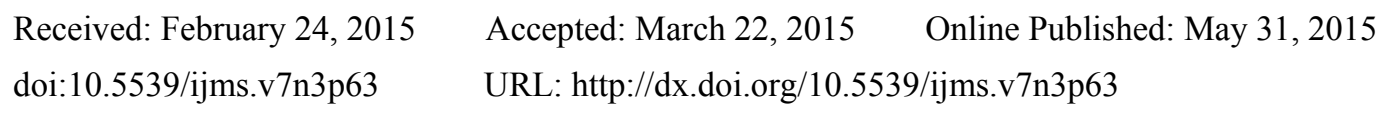

\begin{abstract}
This study tries to investigate if MTN Ghana provides good quality service and to establish the factors that determine the service quality of mobile telecommunication as perceived by MTN customers in Ghana.

The study used both primary and secondary sources of information from the MTN (GH) Ltd employees and its customers. The primary data was mainly from the questionnaires that were administered to MTN customers and the secondary data were annual reports, brochures and manuals from the MTN (GH) Ltd offices. Purposive sampling was used to select which branch of the organization to visit for the study and stratified random sampling was used to select staffs for the study. The study used the SPSS software to run multiple Regression analysis by examining the inter-relationship between Good Quality Service (Dependent variable) and a number of explanatory (Independent) variables such as provision of efficient service, Offers wider range of service, Offers high rates of interests on premium, community mindedness, good customer retention, degree of customer relationship, Introduction of innovative products and Opportunity to complain as factors contributing to good quality service of the MTN.

The results of the analysis revealed that community minded is an independent variable that makes the highest contribution to Good Quality Service. It then identified provision of efficient service as having the highest partial correlation with Good Quality Service, so it was added in the second model, model 2 and offers wider range of service was the next significant variable, so it was added to model 3, and Introduction of innovative products was the next significant variable, so it was added to model 4 and offers high rates of interests on premium was the last significant variable, which was also added to model 5 . The study recommends that the MNT (Ghana) Ltd should improvement the quality of their services, as the services provided by them is perceived by MTN customers to be poor. The study further suggests that MTN needs to provide visible supports including social and infrastructural support to communities in which they operate to serve as the strongest advertisement for the MTN Company.
\end{abstract}

Keywords: service quality, customer satisfaction, customer loyalty, good quality service, SERVQUAL

\section{Introduction}

Service quality today has become not only the rhetoric of every business enterprise, but also an important concept in service research. It is virtually impossible for a business organization to survive without building a good quality service provision. Research has shown repeatedly that good quality service influence organizational outcome such as performance superiority (Poretla \& Thanassoulis, 2005), increasing sales profit (Kish, 2000; Duncan \& Elliot, 2002) and market share (Fisher, 2001), improving customer relations, enhance corporate image and promote customer loyalty (Newman, 2001; Caruna, 2002; Ehigie, 2006). In recent times, the search for good quality is debatably the most important consumer trend as consumers are now demanding higher quality products and services than ever before. MTN Ghana is one of the fastest growing sectors of the Ghana economy and there is fierce competition within the sector made up of six telecom operators namely, MTN, TIGO, VODAFONE, AIRTEL, EXPRESSO and GLO. In the context of the relative high number mobile telecommunication providers in Ghana, MTN service providers in Ghana receive complaints from MTN customers expressing their dissatisfaction of MTN services provided recent times. The dissatisfaction of customers has been attributed 
largely to poor quality service delivery by operators and it is often highlighted in the media and widely discussed among the general public. The National Communications Authority (NCA) threatened to crack down on mobile network providers if they fail to tackle the chronic problem of poor quality service. As part of the measures to promote further competition and improve upon good quality service the NCA introduced the Mobile Number Portability (MNP) in July, 2011. As at $31^{\text {st }}$ July, 2011, 25 days of implementation of MNP, as many as 21,000 mobile phone subscribers have successfully ported their mobile numbers (National Communication Authority NCA, 2011). The high number of subscribers who ported within this short period of time confirms the high level of dissatisfaction with the existing service provided and the desire to seek better services elsewhere. Panda (2003) asserted that the success of a service provider depends on the quality relationship with customers which determine a good quality service provision.

\section{Literature Review}

\subsection{Concept of Customer}

Customers are those who buy products or services that are provided by companies, organisations or sellers of products or services. In this sense customers provide payments in exchange for products or services provided by companies, organisations or sellers (providers). People buy products or goods for the products or services to be consumed. This does not imply that customers are necessarily consumers. Also it does not mean that consumers are necessarily customers. This is true because there are people who buy products or services for other people to use and there are also people who use goods or services that are not bought by them. However there are people who use products or services that they buy. That is there are times when customers are at the same time consumers (Solomon, 2009). In this work the use of the term consumer-customer implies those who buy and use mobile telecommunication services provided by MTN.

\subsection{Concept Customer Satisfaction}

The term satisfaction suggests the affective state of consumer-customers in relation to products or services. That is consumer-customers of MTN are said to be satisfied if they are content with the products or services provided by MTN. In a broader sense, the term satisfaction means the consumer-customer's feeling of pleasure or displeasure that results from his or her comparison of the product's or service's perceived performance or outcome with his or her expectations (Kotler \& Keller, 2009). Conclusively, satisfaction is either the state of pleasure or happiness derived by consumer-customers from the consumption of the products or services that are provided by a specified person or group of people. The above arguments notwithstanding, satisfaction is sometimes subjective which means that some people do not like what others like. In this case, it is sometimes very difficult to satisfy everyone at the same time.

Many organisations pay a lot of attention to the happiness of their consumer-customers to attain competitive advantage. For these organisations customer happiness is a sign of customer satisfaction. This suggests that satisfaction is the customer-consumer post-purchase and post-consumption overall evaluation of the perceived discrepancy or gap between his or her expectation and perceived performance. These evaluations take place either at the cognitive or affective levels or both (Giese \& Cote, 2000). Therefore several scholars argue that satisfaction involves cognitively judging specified products or services and affectively reacting towards the said products or services (Gronroos, 2001; Edvardsson et al., 2005; Martin, et al., 2008). The narrower the discrepancy or gap between the consumer-customer's expectation and his or her perceived performance the greater the satisfaction of consumer-customer. Again, the greater the discrepancy or gap between the consumer-customer's expectation and his or her perceived performance the greater the dissatisfaction of the consumer- customers (Kotler et al., 2002; Schiffman \& Karun, 2004).

\subsection{Concept of Customer Loyalty}

Customer loyalty can be defined in two distinct ways. First, loyalty is an attitude. Different feelings create an individual's overall attachment to a product, service, or organization. These feelings define the individual's (purely cognitive) degree of loyalty. The second definition of loyalty is behavioral. Examples of loyalty-behaviour include continuing to purchase services from the same supplier, increasing the scale and or scope of a relationship, or the act of recommendation (Yi, 1990). Customer loyalty is developed over a period of time from a consistent record of meeting, and sometimes even exceeding customer expectations (Teich, 1997). Kotler et al. (1999) asserted that the cost of attracting a new customer may be five times the cost of keeping a current customer happy. Furthermore, Gremler and Brown (1996) noted that the degree to which a customer exhibits repeat purchasing behavior, possesses a positive attitudinal disposition toward the provider, and considers using only this provider when a need for this service exists. 
Bloemer \& Kasper (1995) hold a contrary view about customer loyalty. According to them, Loyalty may be interpreted as true loyalty rather than repeat purchasing behavior, which is the actual re-buying of a brand, regardless of commitment. Zeithaml et al. (1996) states loyalty is a multi-dimensional construct and includes both positive and negative responses. However, a loyal customer may not necessarily be a satisfied customer. Colgate et al. (1996) also noted that it is not always the case that customer defection is the inverse to loyalty, while Levesque and Mc Dougall (1993) suggested that, "even a problem is not solved, approximately half of the customers would remain with the firm".

\subsection{Concept of Quality Service}

The definition of quality and constituents of quality is contestable. This is partly because quality is an elusive and indistinct concept (Parasuraman et al., 1985). It is therefore often construed to mean imprecise adjectives like goodness, or luxury (Crosby, 1979). Unlike a product whose quality can be determined largely by examining its physical features like style, hardness colour, texture, packaging among others, the key characteristics of service are intangibility, heterogeneity and inseparability and there quality cannot easily be measured. First, Zeithaml (1981) noted that most services cannot be measured, counted, inventoried, tested and verified in advance of sale to ensure quality. Thus, the intangible nature of services means, firms may find it difficult to understand how consumers perceive their services. Second, because services are heterogeneous, the nature of the performance often varies from producer to producer, consumer to consumer or from day to day. Consequently, it is difficult to ensure consistency in service delivery (Booms \& Bitner, 1981). Third, production and consumption of many services are inseparable (Carmen \& Langeard, 1980). Therefore quality in services cannot be engineered at the manufacturing plant and delivered to the customers. Hence the concept of quality is subjective since what is perceived as quality by one person may not be considered as quality by another person.

Though the definition of service quality may vary from one person to another and even differs in different situations, it can be assessed by probing whether perceived service delivery meets, exceeds or fails to meet customer expectations (Cronin \& Taylor, 1992; Oliver, 1999). Lewis and Booms (1983) postulated that good quality service is a measure of how well the service level delivered matches consumer expectations. Thus, delivering good quality service means conforming to customer expectations on a consistent basis. Similarly, Parasuraman et al. (1985) defined good quality service as the consumer's comparison between service expectation and service performance.

\begin{tabular}{|c|c|c|c|}
\hline S. No & Broad Category & Author, Year & Definitions \\
\hline 1. & Functional quality & $\begin{array}{l}\text { Parasuraman, Zeithaml } \\
\text { and Berry, } 1988\end{array}$ & $\begin{array}{l}\text { Global judgment or attitude, relating to the superiority } \\
\text { of the service. }\end{array}$ \\
\hline 2. & & $\begin{array}{l}\text { Bitner, Booms and } \\
\text { Tetreauly, } 1990\end{array}$ & $\begin{array}{l}\text { The customer's overall impression of the relative } \\
\text { inferiority/superiority of the organization and its services. }\end{array}$ \\
\hline 3. & & $\begin{array}{l}\text { AsubontengMcCleary } \\
\text { and Swan, } 1996\end{array}$ & $\begin{array}{l}\text { The difference between customer's expectations for } \\
\text { service performance prior to the service encounter and } \\
\text { their perceptions of the service received. }\end{array}$ \\
\hline 4. & Technical quality & $\begin{array}{l}\text { Hannikainen, } \\
\text { et. al., } 2002\end{array}$ & $\begin{array}{l}\text { It is the capability of a network to provide services and } \\
\text { to fulfil user's expectations. }\end{array}$ \\
\hline 5. & & TRAI*2002 & $\begin{array}{l}\text { It is an indicator of performance of a network and of the } \\
\text { degree to which the network conforms to the stipulated norms. }\end{array}$ \\
\hline
\end{tabular}

TRAI: Telecommunication Regulatory Authority of India.

Figure 1. Different definitions of quality service

Source: Seth A, et al., 2008, VIKALPA, Vol. 33, No. 1.

Many organization and scholars are of the view that quality service is important for the survival of organisations in the competitive environments organizations operate. As a result of this realization, there have been many studies to understand the concept of quality service and measure quality service. This notwithstanding there is no agreement on the measurement of quality service (Wisniewski, 2001; Rahaman et al., 2011).

\subsection{Discussions of Components of Quality Service and Related Measurements Tools}

\subsubsection{Customer Satisfaction Dimensions and Measurement}

There several perspectives on measuring customer satisfaction (CS). The cognitivist perspective identified nine dimensions of CS that comprise expectancy disconfirmation, assimilation or cognitive dissonance, contrast, 
assimilation contrast, equity, attribution, comparison-level, generalized negativity and value-precept (Oh \& Parks, 1997; Pizam \& Ellis, 1999). The behaviourist perspective comprises many theories. Out of these theories the most commonly used are the disconfirmation theories and the customer satisfaction index. These in turn have many models of measuring CS including: satisfaction index, specifically the Minnesota Customer Satisfaction Index (MnCSI), satisfaction model, and disconfirmation measures. The satisfaction index especially the Minnesota Customer Satisfaction Index (MnCSI) is very easy to apply; flexible and suitable for any reasonable number of appropriate responses and succinctly captures the tenet variables of the disconfirmation model which are desire and expectation disconfirmations. The disconfirmation models (DMs) measures customer satisfaction on the basis of the gap or disparity between a cognitive or emotional standard and the perceived performance and uses either the desire disconfirmation scale or expectation disconfirmation scale. The disconfirmation scale has five scale points and has been classified by Danaher and Haddrell (1996), Devlin et al. (1993) and Rust \& Oliver (1994) as the preferred method for measuring customer satisfaction because it has a high predictive validity. The third measure is satisfaction model and uses scales from very satisfied to very dissatisfied to measure satisfaction (Danaher \&Haddrell, 1996). It is said to measure the overall satisfaction of the customers with the services of the network industry. Below is the conceptual framework of the three models of measuring satisfaction described above. The disconfirmation model is divided into the desire disconfirmation and the expectation disconfirmation. The measurement models described above are all quantitative tools.

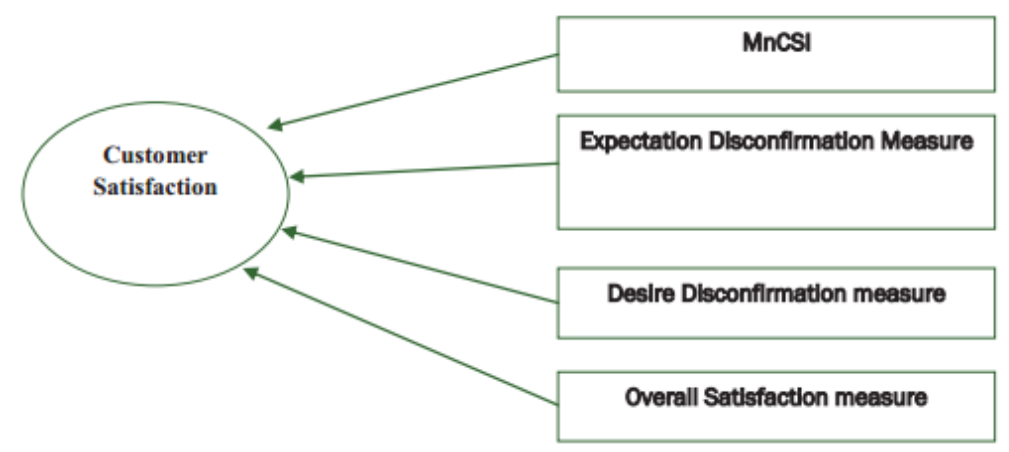

Figure 2. Three conceptual model for measuring CS

Source: Nimako S. G. et al. (2010).

Levy (2009) however recognized that satisfaction is difficult to measure and for this reason he recommended the use of both qualitative and quantitative tools. To this end he suggested three ways of measuring satisfaction:

$>$ Soliciting responses through questionnaire and transforming them into a data

$>$ Discussion involving a seasoned moderator and a focus-group to solicit responses from the focused-group

$>$ Interviewing individuals to solicit their individual responses

\subsection{Quality Service Dimensions}

Scholars do not agree on the number of components and/or factors that constitute service quality. These scholars have similarly not agreed on a uniform tool for measuring service quality. One of the key reasons for which there is no agreement on the measurement of quality service is that several scholars have suggested different labels and quantity of the classifications of quality service. While Lehtinen and Lehtinen (1982) held that there are interactive, physical and corporate dimensions of quality service, Gronroos (1984) classifies quality service into technical, functional and reputational dimensions. Similarly, while Leblanc and Nguyen (1988) proposed that quality service has five components namely corporate image, internal organization, physical support of the service producing system, staff customer interaction, and the level of customer satisfaction, Garvin (1988) argued that there are nine dimensions of quality service including performance, features, conformance, reliability, durability, service, response, aesthetic, and reputation. PZB (1988) disagreed with the previous scholars. He held that quality service comprise of five dimensions namely tangibles, reliability, responsiveness, assurance and empathy that are measured using a 22 item scale. The conceptualization of PZB (1988) led to the development of the SERVQUAL instrument for measuring quality service. Hedvall and Paltschik (1989) also held a different view. According to them, there are two sets of quality service dimensions comprising willingness and ability to serve and physical and psychological access. Oliver and Rust (1994) modeled their classification of quality 
service on that of Gronroos' classification of quality service. According to Oliver and Ruth (1994) the dimensions of quality service are functional quality, technical quality and environmental quality.

\begin{tabular}{|c|c|c|c|c|c|c|}
\hline $\begin{array}{l}\text { Authors } \\
\text { (Year) }\end{array}$ & $\begin{array}{l}\text { Parasuraman, } \\
\text { Zeithaml and } \\
\text { Berry (1988) }\end{array}$ & $\begin{array}{l}\text { Lehtinen } \\
\text { and Lehtinen } \\
\text { (1991) }\end{array}$ & $\begin{array}{l}\text { Rosen and } \\
\text { Karwan } \\
(1994)\end{array}$ & $\begin{array}{l}\text { Johnson, Tsiros } \\
\text { and Lancioni } \\
\text { (1995) }\end{array}$ & $\begin{array}{l}\text { Siu and } \\
\text { Cheung } \\
(2001)\end{array}$ & $\begin{array}{l}\text { Alzola and } \\
\text { Robaina } \\
\text { (2005) }\end{array}$ \\
\hline $\begin{array}{l}\text { Application } \\
\text { areas }\end{array}$ & $\begin{array}{l}\text { Telephone co., } \\
\text { securities } \\
\text { brokerage, } \\
\text { insurance co., } \\
\text { banks and } \\
\text { repair and } \\
\text { maintenance }\end{array}$ & $\begin{array}{l}\text { Lunch } \\
\text { restaurants, } \\
\text { Disco, } \\
\text { Pub type } \\
\text { restaurants }\end{array}$ & $\begin{array}{l}\text { Teaching, } \\
\text { restaurant, } \\
\text { bookstore and } \\
\text { health care }\end{array}$ & $\begin{array}{l}\text { Bank } \\
\text { Customers } \\
\text { UK }\end{array}$ & $\begin{array}{l}\text { Service } \\
\text { quality } \\
\text { delivery } \\
\text { of a } \\
\text { department } \\
\text { store chain }\end{array}$ & $\begin{array}{l}\text { Electronic } \\
\text { commerce } \\
\text { B2C }\end{array}$ \\
\hline \multirow[t]{6}{*}{ Dimensions } & Reliability & $\begin{array}{l}\text { Physical } \\
\text { quality }\end{array}$ & Reliability & $\begin{array}{l}\text { Input } \\
\text { quality }\end{array}$ & $\begin{array}{l}\text { Personal } \\
\text { interaction }\end{array}$ & Reliability \\
\hline & Responsiveness & $\begin{array}{l}\text { Corporate } \\
\text { quality }\end{array}$ & Responsiveness & $\begin{array}{l}\text { Process } \\
\text { quality }\end{array}$ & Policy & Design \\
\hline & Assurance & $\begin{array}{l}\text { Interactive } \\
\text { quality }\end{array}$ & Tangibles & $\begin{array}{l}\text { Output } \\
\text { quality }\end{array}$ & $\begin{array}{l}\text { Physical } \\
\text { appearance }\end{array}$ & Guarantee \\
\hline & Empathy & $\begin{array}{l}\text { Process } \\
\text { quality }\end{array}$ & Access & & Promises & Empathy \\
\hline & Tangibles & $\begin{array}{l}\text { Output } \\
\text { quality }\end{array}$ & $\begin{array}{l}\text { Knowing the } \\
\text { customer }\end{array}$ & & $\begin{array}{l}\text { Problem } \\
\text { solving }\end{array}$ & Security \\
\hline & & & Assurance & & Convenience & \\
\hline
\end{tabular}

Figure 3. Different frameworks of service quality dimensions

Source: Seth A, et al, 2008, VIKALPA, Vol. 33, No. 1.

\section{Methodology}

\subsection{Data Sources}

The study made an extensive use of both primary and secondary sources of information from the MTN (GH) Ltd employees and its customers.

\subsection{Primary Data}

The primary sources of data included information that was gathered from the questionnaires that were administered to the respondents at various branches. The advantage of using primary data is that, they are more reliable since they come from the original sources and are collected especially for the purpose of the study.

\subsection{Secondary Data}

The secondary sources of data included MTN (GH) Ltd annual reports, brochures and manuals. A number of both published and unpublished materials on customer service in the telecommunication industry and effects from journals and articles as much as possible were used. Data collected from the secondary sources significantly complemented primary data and enhanced the interpretation of the results (Batsa, 2008).

Purposive sampling was also used to select which branch of the organization to visit for the study. This is guided by the fact that even though there are other branches within the country, however all of them could not be chosen for the study. Simple random sampling was important to the study, since the study was intended to ensure some randomness and representativeness in the sample. The selection of the respondents for the study was guided by sampling procedure: the process involving sampling frame identification and the determination of relevant sample size. At the targeted branch, stratified random sampling was used to select staffs for the study. This was guided by the structure of leadership that is in use by the organization. This method of sampling therefore ensured that staffs in the clerical/technical, supervisory and managerial categories were contacted.

\subsection{Data Analysis}

The study used the SPSS software to run multiple Regression analysis by examining the inter-relationship between Good Quality Service (Dependent variable) and a number of explanatory (Independent) variables such as provision of efficient service (b1), Offers wider range of service (b2), Offers high rates of interests on premium (b3), community mindedness (b4) good customer retention (b5), degree of customer relationship (b6), Introduction of innovative products (b7), Opportunity to complain (b8), as factors contributing to good quality service of the MTN.

Mathematically: 
$\boldsymbol{Y}$ Good Quality Service $=\mathrm{a}_{0}+\mathrm{a} 1 \mathrm{~b}_{1}+\mathrm{a} 2 \mathrm{~b}_{2}+\mathrm{a} 3 \mathrm{~b}_{3}+\mathrm{a} 4 \mathrm{~b}_{4}+\mathrm{a} 5 \mathrm{~b} 5+\mathrm{a} 6 \mathrm{~b} 6+\mathrm{a} 7 \mathrm{~b} 7+\mathrm{a} 8 \mathrm{~b} 8+\boldsymbol{\varepsilon}$;

Where $\boldsymbol{Y}$ is the Good Quality Service, the dependent variable,

b1 is the provision of efficient service

b2 is the Offers wider range of service

b3 is the Offers high rates of interests on premium

b4 is the community mindedness

b5 is the good customer retention

b6 is the degree of customer relationship

b7 is the Introduction of innovative products

b8 is the Opportunity to complain

Where $a_{0}, a_{1}, a_{2}, a_{3}, a 4, a 5, a 6, a 7$ and $a_{8}$ are unknown constants whose values are estimated by the regression analysis from the SPSS output

$\varepsilon$ is the random error term.

\section{Results and Analysis}

\subsection{Introduction}

The study developed quantitative data from the responses to questionnaires. The data was put into SPSS software and was run. The output was interpreted into histograms and tables and a descriptive statistics was done using Microsoft Excel to produce pie chart, bi-chart and histogram. These were authenticated by the use of inferential statistic in the form of multiple regressions to examine the inter-relationship between the dependent variable which is good quality service and a number of explanatory or independent variables such as provision of efficient service (b1), Offers wider range of service (b2), Offers high rates of interests on premium (b3), community mindedness (b4) good customer retention (b5), degree of customer relationship (b6), Introduction of innovative products (b7), Opportunity to complain (b8).

\subsection{Findings and Analysis}

\subsubsection{Customers Demographic}

We start this section by looking at the demographics of both the customers and staff of MTN Ghana. This is to help understand the nature of the respondents. It will also help discover the perception

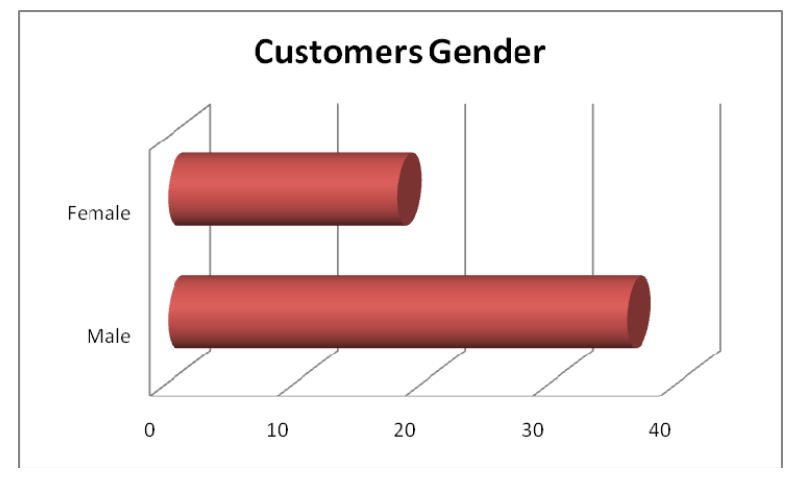

Among the respondents, there were more male (36) respondents than female (18) respondents as shown in figure 1 above. 


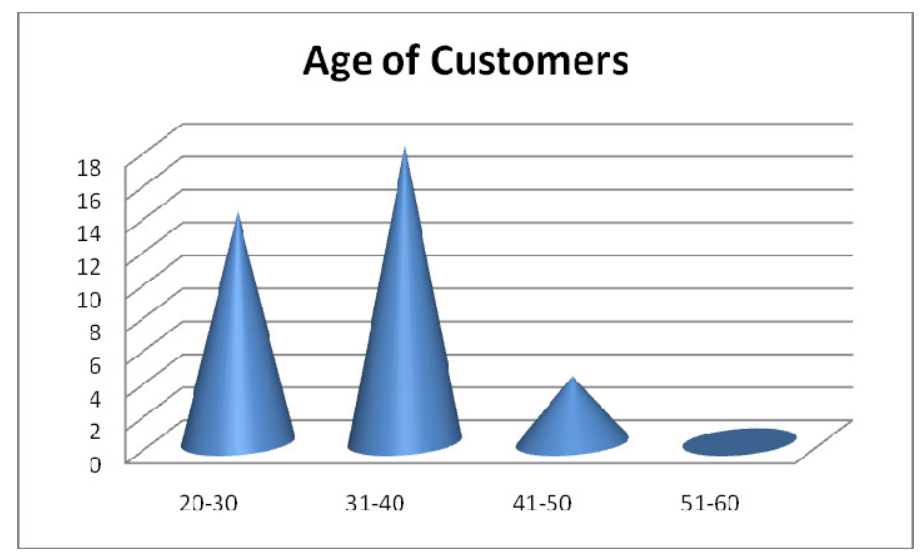

With regards to the age of customers, those are in the age brackets of 20-30 (21) were not significantly different from those who are within the age range of 31-40 (27). However few respondents (6) were within the age bracket of 41-50 and there was none of the customers who are within the age range of 51-60.

The respondents were asked to state the number of years they have been with the company. There were mix responses ranging from 2 to 8 years and above as shown in the graph below.

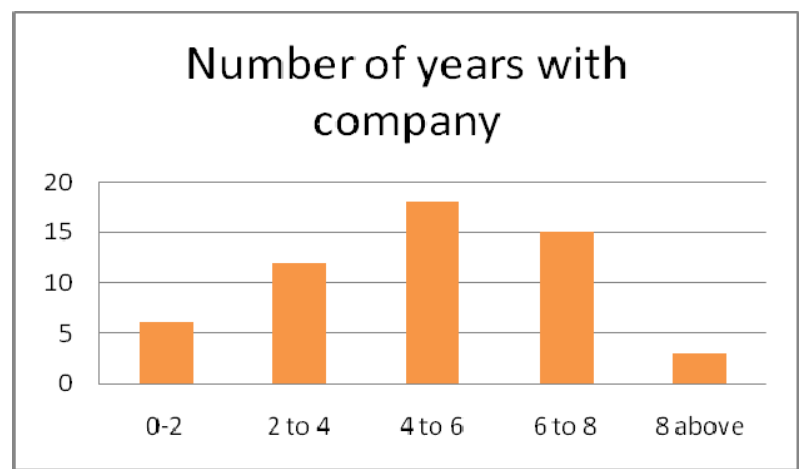

\subsubsection{Staff Profile}

The profile of staff was equally examined and it was revealed that $72 \%$ of the respondents among the staff were male and the remaining $28 \%$ were female as can be seen in figure 3 below.

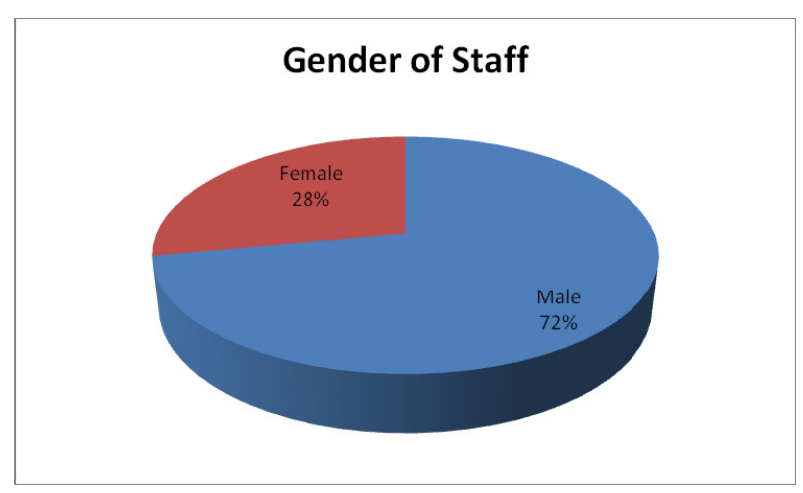

The Staff age profile was looked into and it was revealed that $50 \%$ were between $31-40,39 \%$ were between 20-30, $11 \%$ were between $41-50$ and $0 \%$ was between 51-60. 


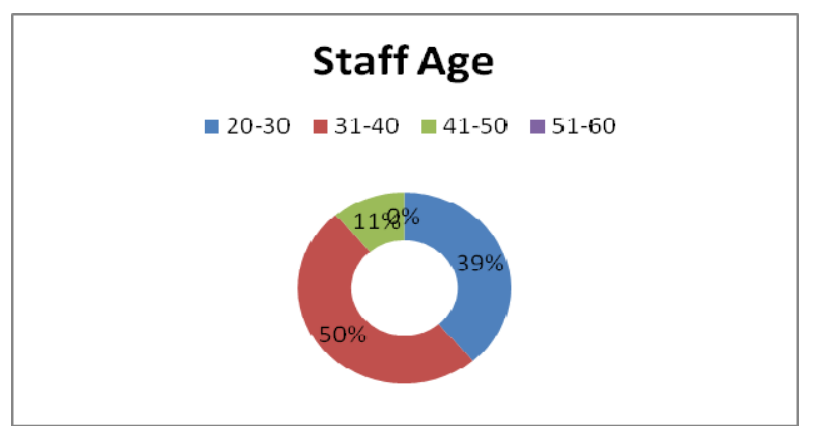

With regards to the number of years the staff is with the company, there were different years ranging from 2 to 12 years.

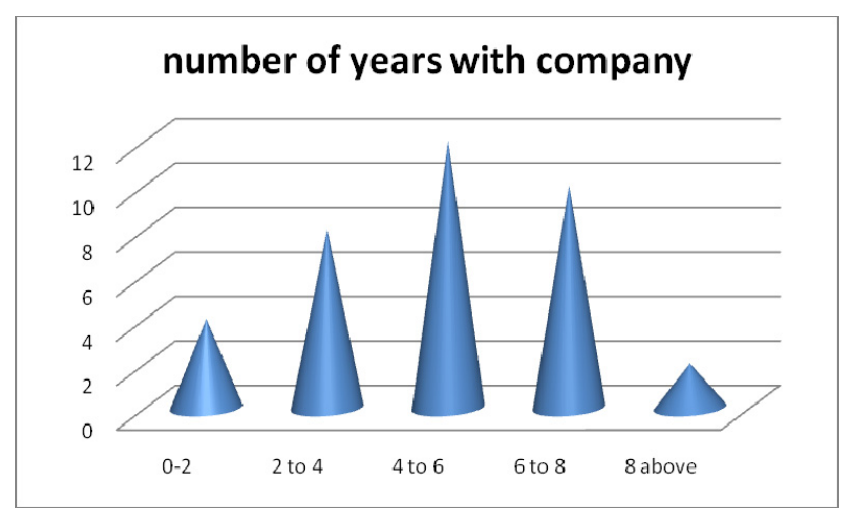

\subsection{Modeling Good Quality Service of MTN Ghana}

The study used the SPSS software to run multiple Regression analysis by examining the inter-relationship between Good Quality Service (Dependent variable) and a number of explanatory (Independent) variables such as provision of efficient service (b1), Offers wider range of service (b2), Offers high rates of interests on premium (b3), community mindedness (b4) good customer retention (b5), degree of customer relationship (b6), Introduction of innovative products (b7), Opportunity to complain (b8), as factors contributing to good quality service of the MTN

Mathematically:

$\boldsymbol{Y}$ Good Quality Service $=\mathrm{a}_{0}+\mathrm{a}_{1} \mathrm{~b}_{1}+\mathrm{a} 2 \mathrm{~b}_{2}+\mathrm{a} 3 \mathrm{~b}_{3}+\mathrm{a} 4 \mathrm{~b}_{4}+\mathrm{a} 5 \mathrm{~b} 5+\mathrm{a} 6 \mathrm{~b} 6+\mathrm{a} 7 \mathrm{~b} 7+\mathrm{a} 8 \mathrm{~b} 8+\varepsilon ;$

Where $\boldsymbol{Y}$ is the Good Quality Service, the dependent variable,

b1 is the provision of efficient service

b2 is the Offers wider range of service

b3 is the Offers high rates of interests on premium

b4 is the community mindedness

b5 is the good customer retention

b6 is the degree of customer relationship

b7 is the Introduction of innovative products

b8 is the Opportunity to complain

Where $a_{0}, a_{1}, a_{2}, a_{3}, a 4, a 5, a 6, a 7$ and $a_{8}$ are unknown constants whose values are estimated by the regression analysis from the SPSS output

$\varepsilon$ is the random error term. 
Table 1. Coefficients ${ }^{\mathrm{a}}$

\begin{tabular}{|c|c|c|c|c|c|c|c|c|c|c|}
\hline \multicolumn{2}{|c|}{ Model } & \multicolumn{2}{|c|}{$\begin{array}{l}\text { Unstandardized } \\
\text { Coefficients }\end{array}$} & \multirow{3}{*}{$\begin{array}{l}\text { Standardized } \\
\text { Coefficients } \\
\text { Beta }\end{array}$} & \multirow[t]{3}{*}{$\mathrm{t}$} & \multirow[t]{3}{*}{ Sig. } & \multicolumn{2}{|c|}{$\begin{array}{l}95.0 \% \text { Confidence } \\
\text { Interval for B }\end{array}$} & \multicolumn{2}{|c|}{$\begin{array}{l}\text { Collinearity } \\
\text { Statistics }\end{array}$} \\
\hline & & $\mathrm{B}$ & Std. & & & & Lower & Upper & Tolerance & VIF \\
\hline & & & Error & & & & Bound & Bound & & \\
\hline \multirow[t]{2}{*}{1} & (Constant) & -3.668 & 1.693 & & -2.167 & .035 & -7.064 & -.271 & & \\
\hline & community minded & 14.894 & .732 & .943 & 20.355 & .000 & 13.426 & 16.363 & 1.000 & 1.000 \\
\hline \multirow[t]{3}{*}{2} & (Constant) & -8.655 & 1.492 & & -5.800 & .000 & -11.651 & -5.659 & & \\
\hline & community minded & 8.338 & 1.162 & .528 & 7.173 & .000 & 6.005 & 10.672 & .224 & 4.465 \\
\hline & $\begin{array}{l}\text { provision of efficient } \\
\text { service }\end{array}$ & 7.064 & 1.103 & .471 & 6.402 & .000 & 4.849 & 9.279 & .224 & 4.465 \\
\hline \multirow[t]{4}{*}{3} & (Constant) & -15.642 & 1.867 & & -8.378 & .000 & -19.393 & -11.892 & & \\
\hline & community minded & 5.162 & 1.152 & .327 & 4.479 & .000 & 2.847 & 7.476 & .155 & 6.436 \\
\hline & $\begin{array}{l}\text { provision of efficient } \\
\text { service }\end{array}$ & 7.406 & .914 & .494 & 8.107 & .000 & 5.571 & 9.242 & .223 & 4.490 \\
\hline & $\begin{array}{l}\text { offers wider range of } \\
\text { service }\end{array}$ & 7.637 & 1.533 & .231 & 4.981 & .000 & 4.557 & 10.716 & .384 & 2.602 \\
\hline \multirow[t]{5}{*}{4} & (Constant) & -18.196 & 1.844 & & -9.869 & .000 & -21.901 & -14.491 & & \\
\hline & community minded & 4.697 & 1.052 & .297 & 4.466 & .000 & 2.583 & 6.810 & .153 & 6.542 \\
\hline & $\begin{array}{l}\text { provision of efficient } \\
\text { service }\end{array}$ & 6.698 & .852 & .447 & 7.863 & .000 & 4.986 & 8.410 & .210 & 4.764 \\
\hline & $\begin{array}{l}\text { offers wider range of } \\
\text { service }\end{array}$ & 6.089 & 1.458 & .184 & 4.176 & .000 & 3.159 & 9.019 & .348 & 2.871 \\
\hline & $\begin{array}{l}\text { Introduction of } \\
\text { innovative products }\end{array}$ & 2.873 & .829 & .145 & 3.466 & .001 & 1.207 & 4.539 & .388 & 2.579 \\
\hline \multirow[t]{6}{*}{5} & (Constant) & -32.375 & 3.155 & & -10.260 & .000 & -38.719 & -26.030 & & \\
\hline & community minded & 2.060 & .999 & .130 & 2.062 & .045 & .051 & 4.069 & .112 & 8.925 \\
\hline & $\begin{array}{l}\text { provision of efficient } \\
\text { service }\end{array}$ & 3.387 & .949 & .226 & 3.570 & .001 & 1.479 & 5.295 & .112 & 8.936 \\
\hline & $\begin{array}{l}\text { offers wider range of } \\
\text { service }\end{array}$ & 7.728 & 1.228 & .234 & 6.291 & .000 & 5.258 & 10.198 & .324 & 3.082 \\
\hline & $\begin{array}{l}\text { Introduction of } \\
\text { innovative products }\end{array}$ & 4.190 & .722 & .211 & 5.805 & .000 & 2.739 & 5.641 & .338 & 2.956 \\
\hline & $\begin{array}{l}\text { offers high rates of } \\
\text { interests on premium }\end{array}$ & 6.020 & 1.179 & .315 & 5.107 & .000 & 3.650 & 8.390 & .117 & 8.513 \\
\hline
\end{tabular}

a. Dependent Variable: Good Quality Service.

Additionally, the choice of the software (SPSS) was appropriate in this type of study because the data was quantitative in nature and the calibration of the questionnaire was in likert format. The SPSS software matches with the stepwise approach that was used for the regression analysis. The regression analysis requires that you use one dependent variable and a number of independent variables and the stepwise selects the most significant independent variables and get rid of the insignificant variables.

\subsection{Hypothesis Testing}

A test of hypothesis was conducted using chi-square test to either accept the null hypothesis (Ho): MTN does not provide quality service and reject the Alternative hypothesis (H1): MTN does provide quality service or accept the alternative hypothesis (H1): MTN does provide quality service and reject the null hypothesis (Ho): MTN does not provide quality service. The margin of error for the analysis was $5 \%$ meaning that there was $95 \%$ accuracy in testing the hypothesis.

Table 2. Chi-Square Tests

\begin{tabular}{llll}
\hline & Value & df & $\begin{array}{l}\text { Asymp. Sig. } \\
(2-\text {-sided })\end{array}$ \\
\hline Pearson Chi-Square & $108.000^{\mathrm{a}}$ & 106 & .428 \\
Likelihood Ratio & 107.463 & 106 & .442 \\
Linear-by-Linear Association & 42.036 & 1 & .000 \\
N of Valid Cases & 54 & & \\
\hline
\end{tabular}

a. 162 cells $(100.0 \%)$ have expected count less than 5 . The minimum expected count is .22 . 
The use of chi-square to test the null hypothesis against the alternative hypothesis required either passing Pearson chi-square or Likelihood Ratio test or Linear-by-Linear Association test or all or some of the tests. This means passing at least one of the tests at a significant level of 0.05 to accept the null hypothesis. The Alternative hypothesis is accepted if the null hypothesis is not accepted at a 0.05 level.

The linear-by-linear association test accepted the null hypothesis: (Ho): MTN does not provide quality service and reject the Alternative hypothesis (H1): MTN does provide quality service. We therefore conclude that base on the test result; we accept the null hypothesis (Ho) and reject the alternative hypothesis.

\section{Summary of Findings, Recommendations and Conclusion}

\subsection{Introduction}

The study scientifically established that community minded has the strongest relationship with the dependent variable followed in sequence of importance by provision of efficient service; offers wide range of service; introduction of innovative products; and offers high rates of interests on premium. In the light of the aforementioned findings, it is clear that the factors of good quality service are: community minded; provision of efficient service; offers wide range of service; introduction of innovative products; and offers high rates of interests on premium. In the light of the aforementioned findings, it is clear that the factors of good quality service are. The Key implications of these findings is that the company that is perceived as being community minded through its social and infrastructural support to the community will attract the most customers and therefore attain the highest competitive advantage.

\subsection{Summary of Findings}

* The components and/or factors that constitute community minded; provision of efficient service; offers wide range of service; introduction of innovative products; and offers high rates of interests on premium

* Community minded which was identified as one of the independent variables has the strongest relationship with the dependent variable which is good quality service

* Offers high rates of interests on premium was another independent variables and has the weakest relationship with the dependent variable which is good quality service

* While the employees of MTN perceived that their company provides good quality services, the customers of MTN in Ghana perceived that MTN provides poor quality services.

\subsection{Recommendation}

Improvement of the quality of services: The quality of services provided by MTN as perceived by MTN customers is poor. In the light of this, it must be noted that the perception of customers influence the level of customer satisfaction and the level of customer satisfaction in turn influence the perception of customers. Furthermore, the nature of the perception and satisfaction of customers determine the customers to behave in one way or the other. If the customers have positive perception of a service and therefore happy with the services provided, they are most likely to continue using the services. If they are not happy with the services because they have negative perception of the services provided, they are most likely to discontinue using the services. It is therefore recommended that MTN improves on the services it provides.

Visible Contributions to community: MTN customers perceive community minded as the key component of quality service. The implication is that MTN needs to provide visible supports including social and infrastructural support to communities in which they operate to service as the strongest advertisement for the MTN Company. This will go a long way to make MTN competitive and attain competitive advantage.

\subsection{Conclusion}

It is clear so far that MTN customers in Ghana are not happy with the services MTN provides. In this regard MTN needs to do more of customer satisfaction survey and depend less on the opinion of the employees regarding the quality of services MTN provides. MTN needs to be community minded above all and be perceived to be so. This will make MTN competitive. It is recommended that a research of this nature needs to be repeated using secondary data from MTN and mixed methods to gather the data and process the data.

\section{References}

Anton, C., Camarero, C., \& Carrero, M. (2007). The mediating effect of satisfaction on consumers' switching intention. Psychology \& Marketing, 5(24), 511-538. http://dx.doi.org/10.1002/mar.20171 
Aydin, S., \& Ozer, G. (2005). The analysis of antecedents of customer loyalty in the Turkish mobile telecommunication market. European Journal of Marketing, 6(39), 910-925. http://dx.doi.org/10.1108/03090560510601833

Bauer, H. H., Falk, T., \& Hammerschmidt, M. (2006). eTransQual: A transaction process-based approach for capturing service quality in online shopping. Journal of Business Research, 59(7), 866-875. http://dx.doi.org/10.1016/j.jbusres.2006.01.021

Brooks, R. F., Lings, I. N., \& Botschen, M. A. (1999). Internal marketing and customer driven wavefronts. Service Industries Journal, 19(4), 49-67. http://dx.doi.org/10.1080/02642069900000044

Buttle, F. (1996). SERVQUAL: Review, critique, research agenda. European Journal of Marketing, 30(1), 8-25. http://dx.doi.org/10.1108/03090569610105762

Carman, J. M. (1990). Consumer perceptions of service quality: An assessment of the SERVQUAL dimensions. Journal of Retailing, 66(1), 33-35.

Chaston, I. (1994). Internal customer management and service gaps within the UK manufacturing sector. International Journal of Operations and Production, 14(9), 45-56. http://dx.doi.org/10.1108/01443579410066758

Cooper, D. R., \& Schindler, P. S. (2006). Business Research Methods (9th ed.).

Cronin, J. J. Jr., \& Taylor, S. A. (1992). Measuring service quality: a reexamination and extension. Journal of Marketing, 56(8), 55-68. http://dx.doi.org/10.2307/1252296

Cronin, J. J., \& Taylor, S. A. (1994). SERVPERF vs. SERVQUAL: Reconciling Performance-Based andPerceptions Minus Expectations Measurement of Service Quality. Journal of Marketing, 58(1), 125-131. http://dx.doi.org/10.2307/1252256

Cronin, J. J., Jr., Brady, M. K., \& Hult, G. T. M. (2000). Assessing the effects of quality, value, and customer satisfaction on consumer behavioral intentions in service environments. Journal of Retailing, 76, 193-218. http://dx.doi.org/10.1016/S0022-4359(00)00028-2

Crosby, P. B. (1979). Quality is Free: the Art of Making Quality Certain. New York: McGraw-Hill.

Danaher, P. J., \& Haddrell, V. (1996). A com-parison of question scales used for measuring customer satisfaction. International Journal of Ser-vice Industry Management, 7(4), 4-26. http://dx.doi.org/10.1108/09564239610129922

Delvin, S. J., \& Dong, H. K. (1994). Service Quality from the Customer Perspective. Marketing Research, 6(1), $5-13$.

Delvin, S. J., Dong, H. K., \& Brown, M. (1993). Selecting a Scale for Measuring Quality. Marketing Research: A magazine of Management and Applications, 5(3), 12-17.

Edvardsson, A. (2005). GURU'S VIEW, Service quality: beyond cognitive assessment. Managing Service Quality, 15(2), 127-131. http://dx.doi.org/10.1108/09604520510585316

Edvardsson, B., Gustafsson, A., \& Roos, I. (2005). Services portrait in service research: a critical review. International Journal of Service Industry Management, 16(1), 107-121. http://dx.doi.org/10.1108/09564230510587177

Eshghi, A., Roy, S. K., \& Ganguli, S. (2008). Service quality and customer satisfaction: An empirical investigation in Indian mobile Telecommunications services. Marketing Management Journal, 18(2), 119-144.

Giese, J. L., \& Cote, J. A. (2002). Defining Consumer Satisfaction. Academy of Marketing Science, 2000(1), $1-24$.

Gro“nroos, C. (1990). Service Management: A Management Focus for Service Competition. Inter-national Journal of Service Industry Management, 1(1), 6-14. http://dx.doi.org/10.1108/09564239010139125

Gro"nroos, C. (1994). From Marketing Mix to Re-lationship Marketing. Towards a Paradigm Shift Marketing. ASIA- Australia Marketing Journal, 2(1), 9-30. http://dx.doi.org/10.1016/S1320-1646(94)70275-6

Gro“nroos, C. (2000). Service Management and Marketing. Lexington Books, Lexing-ton, MA.

Gro"nroos, C. (2001). The Perceived Quality Con-cept: a mistake? Managing Service Quality, 11(3), 150-152. http://dx.doi.org/10.1108/09604520110393386 
Gro"nroos, C. A. (1984). Service model and its mar-keting implications. European Journal of Market-ing, 18(4), 36-44. http://dx.doi.org/10.1108/EUM0000000004784

Guo, L., Xiao, J. J., \& Tang, C. (2009). Understanding the psychological process underlying customer satisfaction and retention in a relational service. Journal of Business Research, 62(11), 1152-1159. http://dx.doi.org/10.1016/j.jbusres.2008.10.020

Ishaqa, M. I. (2012). Perceived Value, Service Quality, Corporate Image and Customer Loyalty: Empirical Assessment from Pakistan. Serbian Journal of Management, 7(1), 25-36. http://dx.doi.org/10.5937/sjm1201025I

Kotler, P., \& Keller, K. (2006). Marketing Management (12th ed.). Pearson Education Inc, New Jersey.

Kotler, P., \& Keller, K. L. (2009). Marketing management (13th ed.). Upper Saddle River, New Jersey: Pearson Education Inc.

Kotler, P., Armstrong, G., Saunders, J., \& Wong, V. (2002). Principle of Marketing (3rd ed.). Pretence Hall \$Europe.

Leblanc, G., \& Nguyen, N. (2001). Corporate image and corporate reputation in consumers' retention decisions in services. Journal of Retailing and Consumer Services, 8, 227-236. http://dx.doi.org/10.1016/S0969-6989(00)00029-1

Malhotra, N. K., \& Birks, D. F. (2007). Marketing Research, An applied Approach (3rd ed.). Prentice Hall, Inc.

Nimako, S. G., Asumah, F. K., \& Donkor, F. (2010). Overall Customer Satisfaction in Ghana's Mobile Telecommunication Networks: Implications for Management and Policy. ATDF JOURNAL, 7(3/4).

Oliver, R. L. (1980). A cognitive Model of the antrecedents and Consequences of Satisfaction Decisions. Journal of Marketing Research, 17, 460-469. http://dx.doi.org/10.2307/3150499

Oliver, R. L. (1993). A Conceptual Model of Service Quality and Service Satisfaction: Compatible Goals, Different Concepts. In T. A. Swartz, D. E. Bowen, \& S. W. Brown (Eds.), Advances in Services Marketing and Management Research and Practice. Greenwich, CT: JAI Press.

Oliver, R. L. (1999). Whence consumer loyalty. Journal of Marketing, 63(special issue), 33-44. http://dx.doi.org/10.2307/1252099

Oliver, R. L., \& DeSarbo, W. (1988). Response determinants in satisfaction judgments. Journal of Consumer research, 14, 495-507.

Parasuraman, A., Zeithaml, V. A., \& Berry, L. L. (1988). SERVQUAL: A multiple-item scale for measuring consumer perceptions of service quality. Journal of Retailing, 64, 12-40.

Park, J. W., Robertson, R., \& Wu, C. L. (2006). Modelling the Impact of Airline Service Quality and Marketing Variables on Passengers' Future Behavioural Intentions. Transportation Planning and Technology, 29(5), 359-381. http://dx.doi.org/10.1080/03081060600917686

Pizam, A., \& Taylor, E. (1999). Customers Satisfaction and its Measurement in Hospitality Enterprises. International Journal of Contemporary Hospitality Management, 11(7), 326-339. http://dx.doi.org/10.1108/09596119910293231

Rust, R. T., \& Oliver, R. L. (1994). Service quality: insights and managerial implications from the frontier. In R. Rust \& R. Oliver (Eds.), Service Quality: New Directions in Theory and Practice (pp. 1-20). Thousand Oaks, CA: Sage Publications. http://dx.doi.org/10.4135/9781452229102.n1

Satari, S. (2007). Application of Disconfirmation Theory on Customer Satisfaction Determination Model - Case of Prepaid Mobiles in Iran. Master's Thesis, LTU, Sweden.

Saunders, M. N. K. (2000). Research Methods for Business Students (2nd ed.).

Schiffman, L. G., \& LazarKanuk, L. (2004). Consumer Behaviour (8th ed.). New Jersey Pearson Education Inc.

Seth, N., Deshmukh, S. G., \& Vrat, P. (2005). Service quality models: A review. International Journal of Quality \& Reliability Management, 22(9), 913-949. http://dx.doi.org/10.1108/02656710510625211

Wisniewski, M. (2001). Using SERVQUAL to assess customer satisfaction with public sector services. Managing Service Quality, 11(6), 380-388. http://dx.doi.org/10.1108/EUM0000000006279

Wisniewski, M., \& Donnelly, M. (1996). Measuring service quality in the public sector: the potential for SERVQUAL. Total Quality Management, 7(4), 357-365. http://dx.doi.org/10.1080/09544129650034710 
Yi, Y. (1990). Critical Review of Consumer Satisfaction. Review of Marketing, 68-123.

Zeithaml, V. A., Berry, L. L., \& Parasuraman, A. (1996). The behavioral consequences of service quality. Journal of Marketing, 60(3). http://dx.doi.org/10.2307/1251929

Zeithaml, V. A., Parasuraman, A., \& Berry, L. L. (1990). Delivering quality service; Balancing customer perceptions and expectations. New York, NY: The Free Press.

Zeithaml, V., Parasuraman, A., \& Berry, L. (1990). Delivering Quality Service. New York: Free Press.

\section{Copyrights}

Copyright for this article is retained by the author(s), with first publication rights granted to the journal.

This is an open-access article distributed under the terms and conditions of the Creative Commons Attribution license (http://creativecommons.org/licenses/by/3.0/). 